\title{
Susan K. Freeman \\ Sex Goes to School: Girls and Sex Education before the 1960s.
}

Urbana and Chicago: University of Illinois Press, 2008. xvii, 220 pp.

\section{Rebecca Priegert-Coulter}

University of Western Ontario

With the jaunty title, Sex Goes to School, and an introductory promise "to offer a deeper understanding of the dynamic process of sex education" along with a shift "to consider adolescents' perspectives and contributions along with those of educators" $(\mathrm{x})$, this book tempts a reader with possibilities. There is no doubt that Susan Freeman has done an admirable job of scouring the sources to produce an examination of the changing intent and orientation of sex education in the 1940s and 1950s in the United States. Whether the book delivers on its initial promise, however, is another matter.

Sex Goes to School is a short monograph that begins by looking at the transition from a strictly biological and health-based sex education curriculum to one situated more fully in studies of family life, psychological adjustment and happy heterosexual relationships. While this argument about a move from a more morally certain age to a therapeutic present is not new to educational historians, Freeman's tracing of this history is useful and thorough. Her identification of the disagreements and conflicts that would erode the majority support for school-based sex education that she claims was present in the mid-twentieth century is thought-provoking.

Once the stage has been set, the book moves to a closer examination of the ways in which sex education was developed as curriculum. In the strongest, but too short, chapter in the book, three cases are used to explore the newly developed and more open approaches to sex education of the mid-twentieth-century. While acknowledging differences among those active in leading and implementing the new sex education courses in Oregon state, Toms River, New Jersey and San Diego, California, Freeman offers a relatively clear sense of what might actually have happened in the three school jurisdictions selected. In using these examples, she provides the kind of 
empirical evidence and the social context needed to support the specific conclusions that she draws. Paradoxically, the strength of this chapter highlights problems of overgeneralization and unsubstantiated claims in the rest of the study.

It is notoriously difficult for educational researchers to understand and explain how teachers make pedagogical decisions and what they actually do when they teach. Furthermore, it is virtually impossible to determine what sense students make of the material presented to them or how they use it in their lives, let alone evaluate what impact the hidden and evaded curricula may have on student learning. Of course, this has not stopped historians and social scientists, myself included, from extrapolating actual practices and behaviours from prescriptive curriculum documents, teaching materials, writings in academic and professional journals and survey data. Freeman is in good company here but she might have exercised rather more caution and academic humility than she does in forming conclusions about what teachers, instructors and educators did and said and how young people took up the materials and ideas they encountered.

Leaving aside questions about the education, age, preparedness and retention of school teachers in the 1940s and 1950s, how could we know, for example, that "Most educators did not censure tomboys, married women working for wages, and young people who "petted" (xi), that "Instructors often gave up some of their authority to impress students with the principles of democratic cooperation" (28) and that "Teachers aimed to convey respect for sexual anatomy and spoke in uninflected tones" (72)? These uncritical and largely undifferentiated claims about educators tend to romanticize teachers, teaching, and classroom settings, as does the extolling of the "discussion method" as pedagogy. Class discussion was not a new approach to learning in the 1940s and 1950s but rather had a close association with the new education and progressive education movements that arose in an earlier period. And there is considerable research, especially in the feminist and queer literature, to suggest that discussion in a school context is far from democratic and too often reinscribes the power dynamics of gender. Indeed, the few examples of class discussions and activities provided in Sex Goes to School reveal, for the most part, practices that would work to reinforce hegemonic masculinities and femininities and contribute to sexism and homophobia, a reality that Freeman actually draws to the readers' attention. This raises fundamental questions about what evidence Freeman has to support her claims that classrooms were places where "democratic and antipatriarchal ideology" (149) was expressed.

The most intriguing claim in this book is one which ties sex education and family living curricula to the development of a gender consciousness in girls that served to establish their collective identity and sense of inequality, thus creating fertile ground for feminism. Whether it encouraged misogyny, resistance, acceptance or anything else in boys is not clear. But linking one or two courses in sex education or family living that may have been taught by incompetent, embarrassed, ill-informed or socially conservative teachers to the openness of young women to second wave feminism (itself a problematic over-generalization) seems an extraordinary stretch. The suggestion that mainstream psychology provided the wherewithal for the women's 
movement, and the New Left more generally, "to distinguish public and private as well as psychological and social" creates a peculiar dualism that was actually rejected by feminists, seriously misinterprets the claim that "the personal is political," and overlooks the scathing attacks on psychology by leading feminist scholars in that discipline itself, as well as in other fields.

Although it displays a presentist cast in its assumptions about the history of youth, teachers, teaching and schooling, Sex Goes to School does make a contribution to the history of ideas about sex education. It offers a useful reminder that the 1950 s were a lively decade of debate, that curriculum has the potential to shape and be shaped by students, teachers, parents and the broader public, and that schooling ought to be about understanding life, not just preparation for work. 